\title{
Domperidone induced galactorrhea: rare presentation of a common drug
}

\author{
Suman Ruhela ${ }^{1}$, Indira Sahu ${ }^{2}$, Manish Ruhela ${ }^{3 *}$, Rakesh Kumar Ola $^{3}$
}

\author{
${ }^{1}$ Department of Ophthalmology, SK Medical College and Hospital, Sikar, Rajasthan, India \\ ${ }^{2}$ Department of Pathology, CHC, Laxmangarh, Sikar, Rajasthan, India \\ ${ }^{3}$ Department of Cardiology, Noble Care Hospital, Sikar, Rajasthan, India
}

Received: 16 September 2020

Accepted: 12 October 2020

\section{*Correspondence:}

Dr. Manish Ruhela,

Email: dr.manishruhela@gmail.com

Copyright: ( $)$ the author(s), publisher and licensee Medip Academy. This is an open-access article distributed under the terms of the Creative Commons Attribution Non-Commercial License, which permits unrestricted non-commercial use, distribution, and reproduction in any medium, provided the original work is properly cited.

\begin{abstract}
Domperidone is one of the cheapest and also effective anti-emetic drugs which is very commonly used as an over-thecounter drug. Galactorrhoea is a rare side effect of domperidone. We report a case of a female patient who was prescribed domperidone for migraine headache with vomiting. While taking the drug, she developed galactorrhoea, and after discontinuing domperidone therapy, her galactorrhoea subsided.
\end{abstract}

Keywords: Domperidone, Galactorrhoea, Migraine headache

\section{INTRODUCTION}

Domperidone is a prokinetic drug used for diabetic gastroparesis, hiccoughs and vomiting. It is a peripheral D2 receptor antagonist with selective peripheral activity restricted to the upper gastro-intestinal tract. It is not known to cross the blood brain barrier and hence, lacks neurological side effects. Stomach cramps, diarrhoea, constipation, mastalgia are rarer side effects which have been observed. Although domperidone is implicated as a cause of galactorrhoea, online search reported only a few case reports from India. ${ }^{1}$ Hence we are reporting a case of domperidone induced galactorrhoea in which domperidone was used in therapeutic dose.

\section{CASE REPORT}

A 25-year-lod married housewife with no pre-morbidities came with recurrent headache and vomiting episodes, earlier diagnosed as migraine headache. She consulted to ophthalmologist for blurring of vison during episode of headache. Her field of vison, fundus and Magnetic resonance imagining (MRI) brain was normal. She prescribed paracetamol $500 \mathrm{mg}$ SOS and domperidone 10 mg thrice in a day. On 4th day she presented with galactorrhoea. On examination, the patient had tenderness of both breasts with oozing of milk from both nipples, and without any mass on palpation. Her secondary sexual characters and external genitalia were found to be normal. Other systemic examination was normal. She gave no history of taking any other drugs like oral contraceptive pills, anti-depressants, or anti tubercular drugs. On investigations, prolactin level was done using enzyme immune assay which was elevated $(108 \mathrm{ng} / \mathrm{ml})$. Routine investigations included liver, renal, thyroid function (other causes of hyperprolactinemia) were within normal limit. Urine pregnancy test was negative. As other causes of hyperprolactinemia were ruled out, it was ascertained that the oral domperidone could be the culprit in this condition. Domperidone stopped immediately after 6 days galactorrhoea subsided and a repeat prolactin done after 6 days was within normal limit $(8.2 \mathrm{ng} / \mathrm{ml})$. Causality assessment was carried out using the Naranjo scale which showed highly probable causal association. 


\section{DISCUSSION}

Galactorrhoea, the inappropriate discharge of milk containing liquid from the breast, is considered abnormal if persists for longer than 6 months after child birth, or after discontinuation of breast feeding. ${ }^{2}$ It can be physiological as in pregnancy, lactation, chest wall stimulation, sleep, stress, or pathological. Pathological causes are tumors (craniopharyngiomas, prolactinomas), trauma, acromegaly, hypothyroidism, cirrhosis of liver, chronic renal failure. It can be drug induced also. Drugs causing galactorrhoea are phenothiazines, chlorpromazine, perphenazine, haloperidol, metoclopramide, alpha-methyl dopa, reserpine, opiates, ranitidine, amitriptyline, fluoxetine, verapamil, oestrogens. ${ }^{2}$ Most of these drug induced galactorrhoea cases were reported through various case reports. Here we are reporting a case of domperidone induced galactorrhoea. Domperidone is a D2 receptor antagonist, and very poorly crosses the blood brain barrier. So it has a benefit of minimal Central nervous system (CNS) side effects as compared to metoclopramide. Galactorrhoea is a rare side effect of domperidone and only few cases have been reported. One of the first reports on domperidone induced galactorrhoea was from Great Britain in $1983 .^{3}$ Treatment of galactorrhoea depends upon its cause. Drug induced galactorrhoea generally responds to discontinuation of the offending drug. As mentioned in our case, the patient responded well to the discontinuation of the drug. Sometimes the addition of dopamine agonists (bromocriptine or cabergoline) may be required for the management of galactorrhoea. ${ }^{2}$

\section{CONCLUSION}

Domperidone is a common drug used on a daily basis as an antiemetic. Galactorrhoea is an adverse drug reaction not commonly encountered. Hence, physicians should be aware of such unusual side effects of a common drug to avert unnecessary worry and investigations.

Funding: No funding sources

Conflict of interest: None declared

Ethical approval: Not required

\section{REFERENCES}

1. Nijhawan S, Rai RR, Sharma CM. Domperidoneinduced galactorrhoea. Indian J Gastroenterol. 1991;10(3):113.

2. Melmed JS, Jameson L. Disorders of Anterior Pituitary and Hypothalamus. In: Fauci AS (editor). Harrison's Principles of Internal Medicine. 7th edition. New York: McGraw-Hill Co. 2008;2205-6.

3. Cann PA, Read NW, Holdsworth CD. Galactorrhoea as side effect of domperidone. Br Med J (Clin Res Ed). 1983;286:1395-6.

Cite this article as: Ruhela S, Sahu I, Ruhela M, Ola RK. Domperidone induced galactorrhea: rare presentation of a common drug. Int J Basic Clin Pharmacol 2020;9:1735-6. 